\title{
A Field Study on Global R\&D Centers in Korea: Focusing on Global IT Industry Policy with Gap Approach
}

\author{
Sang Sup Cho ${ }^{1}$ and Youngseok Yang ${ }^{2^{*}}$ \\ ${ }^{1}$ Digital Business Department, Hoseo University, \\ ${ }^{2}$ Graduate School of Entrepreneurial Management, Hanbat National University \\ 글로벌 R\&D센터에 대한 현장조사연구: \\ 갭접근방법에 의한 글로벌 IT산업정책중심 \\ 조상섭 ${ }^{1}$, 양영석 ${ }^{*}$ \\ ${ }^{1}$ 호서대학교 디지털비즈니스학부, ${ }^{2}$ 한밭대학교 창업대학원
}

\begin{abstract}
Innovative capacities and performance are essential for the growth of the IT industry and the development of the Korean economy. Global R\&D centers are important sources of innovation in the IT industry. In order to identify the structure of the innovation environment of global R\&D centers in IT industry, we conducted a field survey of 50 global R\&D centers and 50 global R\&D policy experts in IT industry.

According to the empirical results obtained using the Linear Structure Model, it is suggested that, first, with regard to a short-term IT global policy, the direction of the Korean government's policy should act as a trigger to connect the research domain and the market domain; second, the government policy should act as a facilitator to connect the development domain and the research domain in the mid-term period; and, finally, the government's R\&D policy should serve as a disseminator to connect technological capability and the market space domain in the long-term perspective. For an effective way of internationalizing innovation, IT policy planners should regard global IT R\&D centers as the important components of national innovation system and encourage the effective involvements by them in the process of IT industrial innovation.
\end{abstract}

요 약 우리나라 IT산업성장에서 혁신잠재력과 혁신수행능력이 중요한 역할을 했다. 글로벌 R\&D센터는 IT산업의 혁신의 중요한 요소이다. IT산업에서 혁신환경에 대한 글로벌 R\&D센터구조를 파악하기 위하여 R\&D센터구성원과 정 책입안자 각 50 명씩 현장설문을 실시하였다. 본 실증분석결과를 보면 단기적으로 R\&D정책은 연구영역과 시장역역의 인식차이를 해소하는 촉진자로서 역할이 중요하며, 중기적으로 R\&D정책은 개발과 시장의 영격의 인식차이를 좁히는 조정자로 그리고 장기적으로는 기술능력과 시장의 확산 자로서 역할이 중요함을 보여준다. IT 정책입안자는 R\&D정 책에서 글로벌 R\&D센터를 혁신체계의 요소로 활용하는 것이 요구된다.

Key Words : Global R\&D center; Technology Domain; Market Domain; Linear Structure Model.

\section{Introduction}

This research aims to provide the basic information and data required to invigorate the activities of domestic global IT R\&D centers, to encourage them to continue to voluntarily participate in national, public R\&D projects, and to establish IT and industrial policies aimed at establishing a collaborative system with domestic IT research centers. Kuemmerle [7] sees that multinational corporations are pushing to establish global R\&D centers to use overseas $R \& D$ potential with a view to supplementing the potential of their domestic R\&D

*Corresponding Author : Youngseok Yang(ytony@hanbat.ac.kr)

Received September 28, 2009 Revised (1st October 20, 2009, 2nd November 18, 2009) Accepted december 16, 2009 
resources. Thus, the need to identify the overall role of global IT R\&D centers has arisen, as well as to conduct a macro, systematic analysis of their accurate status and function, by reviewing the validity and development direction of domestic global IT R\&D centers, and, in terms of a macro, national innovation viewpoint, their contribution to the national economy.

With regard to the evolution of global R\&D centers, Tennenhous [13] found the most positive, aggressive corporate $\mathrm{R} \& \mathrm{D}$ representative model in the Intel $\mathrm{R} \& \mathrm{D}$ model. The evolution direction of the Intel R\&D model involves the structuring of a simultaneous $R \& D$ system in the initial simple, progressive form of the R\&D system, and then presenting the trend of expanding technology developers from their centers of excellence to diverse research resources including the structuring of overseas research centers. In his report on reviewing the research organization of IBM, McQueeney [8] indicated that the R\&D organization after the 2000s will switch its focus to new businesses and attach greater importance on the significance and function of external cooperative $R \& D$, and that with the recent change in IBM's $R \& D$ center, the company is actively pushing to establish overseas R\&D centers in China and India, among other nations. Also, Howell [2] indicated that GM has newly added overseas R\&D and international product planning functions to its organization, and is pursuing a course of investing its corporate resources in the development of innovative products. Research by Park et al. [10] on the direction of Korea's R\&D evolutional stated that Samsung is shifting from an internal-focused R\&D system to a system of utilizing external R\&D resources and satisfying customer needs, and that the company has begun to structure and utilize global R\&D centers as the driving force behind its $\mathrm{R} \& \mathrm{D}$ activities.

A review of domestic research into existing global R\&D centers was conducted. Samsung's Economic Research Institute [12] proposed a strategic method for activating domestic global R\&D centers, which involves creating an incentive scheme (strong commitment) to enhance domestic R\&D adaptation abilities with a view to overcoming a lack of interconnection with the domestic R\&D environment (analysis of social network). SERRI likewise insisted that in the long term, domestic global R\&D centers should be admitted as domestic NIS leaders(incentive schemes should be developed), there by bolstering their developmental capabilities. However, this analysis targeted the entirety of global R\&D centers, leading to results that are less suitable to the IT industry. The analysis likewise focused on interconnecting innovative players rather than on creating an industrial environment to support the establishment of global R\&D centers, thereby resulting in an insufficient interconnection between the status of R\&D centers and the policies. Next, the research by Korea University of Technology and Education [5] used the BCG market analysis method, which involves technical competitiveness and market attraction, to attempt a global IT R\&D center matching method that corresponds to the needs of technology and the market. However, the research makes it difficult to take a systematic approach to shifting the policy and strategy system from a micro to a macro level, and does not take into account the connection between the market domain (where research results matter in the implementation of technology policies) and the policy domain (the public domain). Lastly, the Korea Industrial Technology Association[4] surveyed the R\&D status of foreign invested corporations ,and identified the strengths and weaknesses of Korea's R\&D investment. However, it did not properly identify and analyze the overall status and difficulties of foreign invested corporations' R\&D centers, but descriptively analyzed the status, thereby leading to a lack in the utility of reasoning.

This research conducted a policy-oriented analysis of domestic global IT R\&D centers with a view to activating them from a macro, holistic viewpoint. A field survey of data on global IT R\&D centers was conducted, making it available as a basic data for future similar research and the establishment of policies. Notably, this research offered a field data-based macro policy direction with regard to the state's role in activating domestic global IT R\&D centers, thereby securing objectivity and suitability. With this backing, the research presented a policy direction for the participation in national $R \& D$ projects, making it available as important data for the establishment of policies on important technology and industries. Thus, the research will be used as data for formulating policies to enhance the importance of the potential capabilities of domestic IT R\&D centers in securing economic and industrial development. It will also 
be used as important basic data in formulating policies aimed at activating participation in national $R \& D$ projects in the IT industry.

In this research, Chapter II reviews existing research into the types of global R\&D centers, and Chapter III presents the status of domestic IT R\&D centers and the results of their analysis. The last Chapter summarizes the results of the analysis and offers policy implications.

\section{Theories on Global R\&D Centers and Analysis Models}

\subsection{Literature Review}

Currently, corporate global R\&D models are changing from the traditional model - the cooperation and network model - to an overall integration model, and are shifting from a simple structuring of innovative systems to a global innovative system using multinational R\&D centers, making the R\&D model very complicated and comprehensive. Thus, the theoretical model for selecting the location of a global R\&D center reflects the evolution of the $R \& D$ centers of international corporations. First, with regard to the factors that determine the nations into which global R\&D centers venture, as well as their location, a technology-centered selection theory was presented to select an appropriate location of R\&D centers in the three fields of - technology development uncertainty (area A); reliable technology development certainty combined with uncertainty about technology development winners (area B); and all certainties (area C) - due to uncertainty about technological development and to the speed of technological change [see Narula, [9]. According to this theory, generally, a global R\&D center shifts to area $\mathrm{A}$, to area $\mathrm{B}$, and then to area $\mathrm{C}$, before eventually shifting to the traditional R\&D center establishment area.

The next theoretic model attempts to recognize $\mathrm{R} \& \mathrm{D}$ centers as being aimed at decentralizing $R \& D$ organizations and targeting $\mathrm{R} \& \mathrm{D}$, as well as to establish R\&D centers with a view to creating markets and technology [see Khurana, [3]]. According to him, of the four types, R\&D centers perform the most central function of $\mathrm{R} \& \mathrm{D}$, and the global $\mathrm{R} \& \mathrm{D}$ centers in the IT industry, as seen with IBM and MS, prefer the technology-centered R\&D center location. Bas et al. [1], from a macro viewpoint, divided R\&D center types into HBE, HBA, TSS, and MSS, analyzed cases in the US, Japan and Korea, and insisted that the largest individual type of global R\&D center found all over the world is the HBA type. He also suggested that there are many MSS and TSS type elementary global R\&D centers distributed in Korea. Lastly, recent analysis similar to that of this research conducted by Kurkawaetal. [6] of Japan's global $R \& D$ centers indicated that Japan's global $R \& D$ centers were mostly of US nationality, and that R\&D centers other thant hose of the US and Europe represented a very small share. As such, their research suggested that the establishment of global R\&D centers is determined by the technological level of the host nation.

The analytical approach taken in the aforementioned existing research considers a method of dividing R\&D center types according to the development levels of the nation into which global $R \& D$ ventures. Likewise, if the host nation is an advanced one, and the installation nation is a developing one, a catch-up type of global $R \& D$ center is pursued, and conversely, if an advanced nation is the installation nation, and the host nation is a developing nation, a global evolution type of $R \& D$ center is pursued. Second, global R\&D centers, according to this researcher's viewpoint, can be divided into internationalization-centered $\mathrm{R} \& \mathrm{D}$ centers, $\mathrm{R} \& \mathrm{D}$ centers pursing technological diversity, domestic industry protection type $\mathrm{R} \& \mathrm{D}$ centers, and $\mathrm{R} \& \mathrm{D}$ centers for applying technology, depending on the industrial environment and a given center's R\&D pursuits. Lastly, there is a theory that determines the location of R\&D centers by comparing technological levels, dividing them into four types according to the size of the RTA index.

In connection with the direction of this research, a research and analysis approach was taken by M. Porter [13] with a view to activating domestic global IT R\&D centers and participation in national public projects; in taking an approach aimed at bolstering national innovative capabilities, the connectivity between the various components of industries is crucial to determining innovative capabilities. Likewise, if the activation of global IT R\&D centers is closely related not only to external factors of the IT industry but also to the business 
environment, the corporate elements of the R\&D centers, and state policies, then it is very important in presenting the direction taken by $\mathrm{R} \& \mathrm{D}$ policies to identify in advance how closely and in which way the factors for determining the establishment of $R \& D$ centers are interconnected. Since the activation of global R\&D centers and the activation of participation in national public projects are closely connected with technical elements, market elements, and policy direction and the means that encourage these, this research approach can reflect these elements simultaneously and systematically, and develop and use an IT industry and national-level, macro and holistic analysis framework, thereby helping to develop an appropriate policy means.

\subsection{Research Methodology}

It is important to identify the motivation of global IT R\&D centers and market activities, as well as the direction of the corresponding policies, with a view to invigorating participation in national public R\&D projects in line with the activation of domestic global IT R\&D centers. Thus, the design of the field survey focused on securing the appropriate policy means in order to appropriately match the global IT R\&D centers' expectations in the field of the public domain with $R \& D$ activities in the actual market domain, as well as on creating such an environment, thereby activating the participation of global IT R\&D centers in state-run public $R \& D$ projects. To this end, it is imperative to conduct a macro-industrial, proactive analysis of the capabilities and purposes of $\mathrm{R} \& \mathrm{D}$ centers, as well as to bridge the gap between the operators of domestic global IT R\&D center s through "bottom-up" and "top-down" approaches, and to analyze R\&D performers' technology and their market connection in order to pursue a desirable policy on technology and industry.

This research, which reflects expert opinion, divided domestic global IT R\&D centers into the following four types: a technology development type global R\&D center which ventures into Korea in order to develop information technology and transform it into products; a technology research type global R\&D center which is domestically based in order to conduct leading research into technology; a market advancement type global R\&D center which aims to upgrade domestic leading customers and products; and a market expansion type global R\&D center which aims to explore and venture into the domestic IT market.

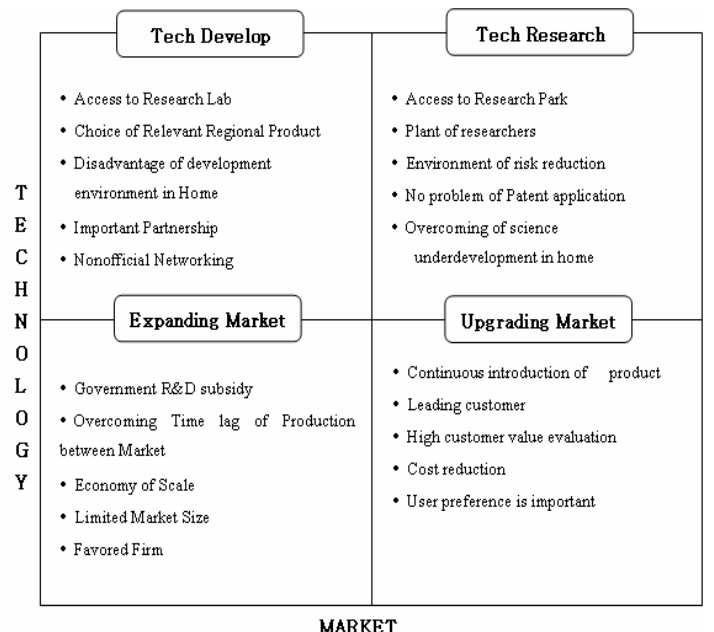

[Fig. 1] Types of Domestic Global IT R\&D Centers used in this research

In addition, a survey of domestic global R\&D centers was conducted after verifying four deterministic factors statistically and conducting a cluster analysis. A structural equation was used to analyze the connectivity between the four factors. As such, this phased-in analysis was intended to analyze the connectivity between R\&D activity factors as seen by personnel engaged in global $R \& D$ centers, and the relevant policy makers' or R\&D-engaged personnel's understanding of the activation of global R\&D centers, thereby identifying the gap and working out desirable policy measures.

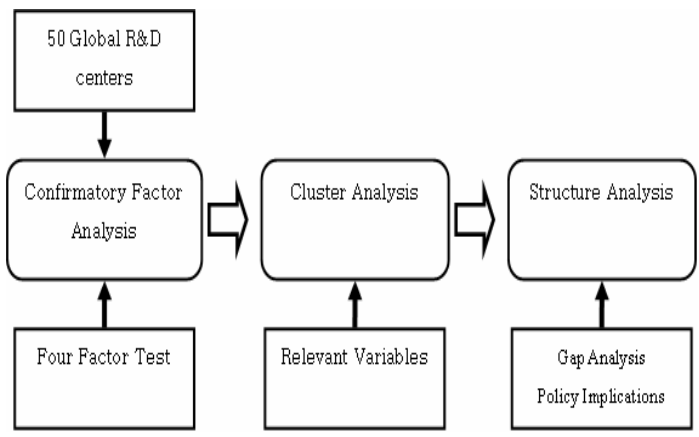

[Fig. 2] Diagram Analysis of the Direction for Activating Global IT R\&D Centers 


\section{Survey of Status of Domestic Global IT R\&D Centers and Its Results}

\subsection{Status of Global IT R\&D Centers}

As of March 2007, 50 global IT R\&D centers and 53 expertise engaged in $R \& D$ policies were surveyed. The results are outlined as follows. First, R\&D centers with 4 to 8 years of operation represented the largest share, and three centers each had 19 years of operation. Second, in terms of the purpose of the establishment of R\&D centers, the largest number of operators aimed to develop technology at the overall corporate level, while in terms of the size of global IT R\&D centers, centers with 6-32 personnel represented the largest number, with one operator employing 190 researchers. Third, in terms of the business activities of the centers, the fields of IT device manufacturing and software represented the highest share, but most of the centers conducted plural business lines. Fourth, in terms of their major activities, the 67 companies conducted patent activity as part of their IT development, and 17 companies participated in public projects. Lastly, personnel engaged in R\&D policy were made up of researchers from public agencies, professors from universities, public servants from municipalities involved in the attraction of $\mathrm{R} \& \mathrm{D}$, and former researchers from public R\&D corporations.

The analysis of the activities of global R\&D centers identified their characteristics as follows. First, global R\&D centers rated the activity of Korea's global R\&D centers as vital (an average score of 6 points), while R\&D policy makers (53) rated it as fair (an average score of 3 points). Statistically, the two groups' opinions proved to be different from each other. By Wilcoxon Rank's verification, the hypothesis that the two groups are different was proved to be statistically significant. Second, the analysis revealed that most of the centers defined research activity as their focusing business, with policy makers rating research activity as important.

[Table 1] Purpose and Direction of Establishment of Global R\&D Centers (median)

\begin{tabular}{|c|c|c|c|c|}
\hline Evaluation & Development & Research & Upgrading market & Expanding market \\
\hline R\&Dcenter & 4.1 & 4.4 & 4.0 & 3.6 \\
Policymakers & 4.8 & 5.0 & 4.6 & 4.8 \\
\hline
\end{tabular}

\subsection{Results of the Analysis of Connectivity Using the Linear Structure Model}

Based on the aforementioned field survey data, a linear structure model was used in order to analyze the connectivity between the four determination factors with regard to the activation of IT R\&D centers. The findings are outlined as follows. First, the ecology of global R\&D centers was found to be good in relation to its market linkage, and the major activities (R\&D) of the centers were also found to be good in relation to their market linkage. Second, the activities of the centers, however, were found to be not linked to their purpose of upgrading the IT market, and the direction of the centers' policies was found to need to be linked with the activation of IT markets and the upgrading of market quality. Notably, the development of information technology was found to have no high connection with the market. Lastly, in order to activate global IT R\&D centers, the linkage between the centers' technology research activities and the upgrading of the market quality should be enhanced, and a structure should be established by which the centers' technology R\&D activities can infiltrate the market domain.

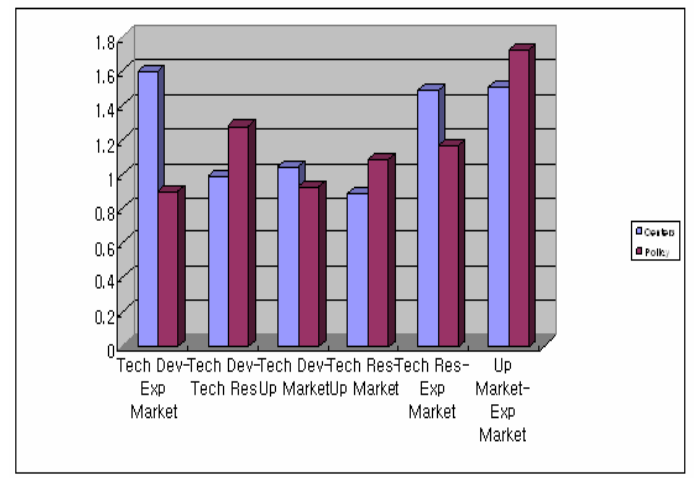

[Fig. 3] Connectivity between Factors of Activating Global IT R\&D Centers

\section{Summary and Policy Implications}

In an effort to activate global IT R\&D centers, the government should clearly define its policy, and global R\&D centers should be seen as technology innovation leaders, while connectivity between their technology R\&D efforts, technologies and the upgrading of the market 
should be established. To this end, in the short term, the centers'sound ecological domain of research and the domain of upgrading the market should be activated. Second, in the mid-term, the linkage between the centers' technologies should be facilitated. Lastly, in the long term, the R\&D policy system should be established in order to fast link the centers' technological capabilities to the market domain (the role of disseminator coordinator).

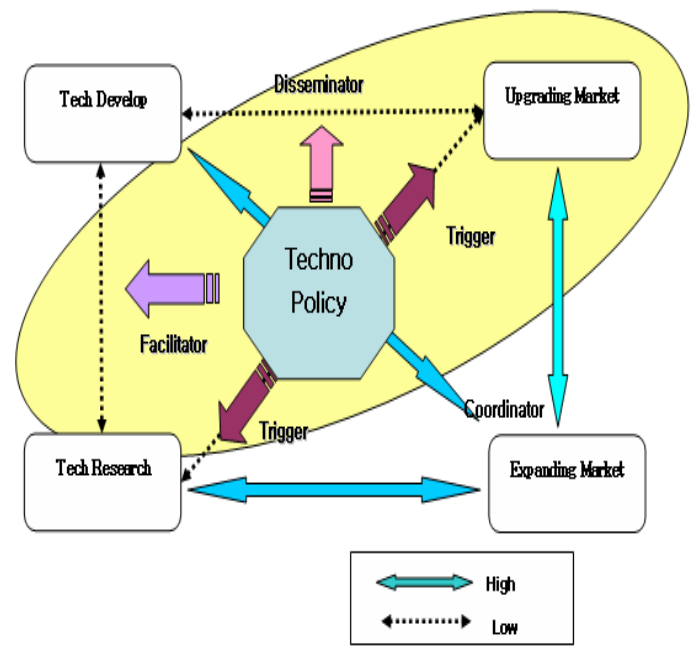

[Fig. 4] Technology Policy for Creating the Ecology of Global R\&D Center

From a holistic perspective, the activation of the centers is determined by IT superiority, Korea's IT industry advancement status, and the nation's global profile in connection with the state's policy management. Thus, the nation's technological and industrial global profiles should be upgraded first of all. To this end, it is important to monitor the centers'business capabilities and scales, which determine their magnitude, and reflect the results in the establishment of R\&D policies. Meanwhile, the factors which determined the centers' participation in public projects were found to be in proportion with the scale of the center involved, and to be in inverse proportion with its business capabilities. This is why the attraction of large-scale R\&D centers and the development of their utilization strategies are needed. An environment should be created in which, at the initial introduction stage, they are motivated to participate in public projects. Likewise, the activation of domestic global IT R\&D centers is seen as going hand in hand with the activation of national public projects.

\section{References}

[1] Bas, C., et al., "Location versus home country advantages in R\&D activities," Research Policy, pp.589-609, 2002.

[2] Howell, L. et al., "Globalization within the Auto Industry, Research. Technology Management, pp.43-49, 2002.

[3] Khurana, A., "Strategies for Global R\&D," Research. Technology Management, pp.48-57, 2006.

[4] Korea Industrial Technology Association, The R\&D Situation and Direction of Foreign Direct Investing Companies, 2007.

[5] Korea University of Technology and Education, The Strategic Field of IT R\&D Centers, 2006.

[6] Kurokawa, S., et al., "Global R\&D activities of Japanese MNCs in the US," Research Policy, forthcoming

[7] Kuemmerle, W. "Building Effective R\&D Capabilities Abroad," Harvard Business Review, pp. 61-70, 1997.

[8] McQueeney, D., "IBM's Evolving Research Strategy, Research. Technology Management, pp.20-27, 2003.

[9] Narula, R., Globalization \& Technology, Polity Press, 2003.

[10] Park, S. et al., "How Samsung Transformed Its Corporate R\&D Center," Research. Technology Management, pp.24-29, 2006.

[11] Porter, M., The Competitive Advantage of Nations, The Free Press, 1990.

[12] Samsung's Economic Research Institute, The Characteristics and Interaction of Global R\&D Centers in Korea, 2006.

[13] Tennenhouse, D., "Intel's Open Collaborative Model of Industry-University Research," Research. Technology Management, pp.19-26, 2004. 
Sang Sup Cho

[Regular Member]

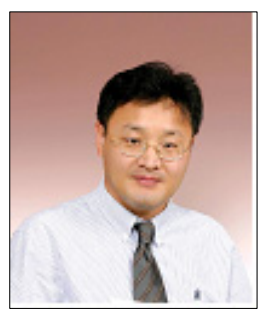

- Feb. 1987 : Hanyang Univ., Economics, MA.

- May. 1996 : Missouri Univ., Accounting, MS.

- May. 1999 : St. Louis Univ. Economics., Ph.D.

- Feb. $2000 \sim 2006$ : ETRI

- Feb. $2006 \sim$ current : Hoseo Univ, Professor

$<$ Research Interests $>$

R\&D Evaluation, Empirical Analysis for IT, Inequality of Economic Activity

\section{Yang, Youngseok}

[Regular Member]

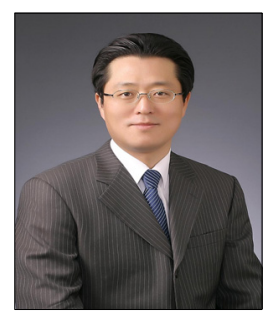

- Aug. 1991 : Stephen F Austin State University (MBA), USA

- Aug. 1996 : University of Nebraska-Lincoln (Ph.D), USA

- May. $1999 \sim$ Sep. 2005 : ETRI, Senior Researcher in R\&D Planning Dept.

- Oct. $2005 \sim$ current : Professor at Graduate School of Entrepreneurial Management in Hanbat National University

$<$ Major Interest $>$

Entrepreneurship, Venture Management, Technology Commercialization, KOSDAQ 